\title{
The Effect of Joining Non-Formal Education and English Achievement
}

\author{
Sherly Marliasari' dan Riris Oktaviani ${ }^{2}$ \\ 1,2Universitas Muhammadiyah Palembang \\ 1sherlymarliasari@gmail.com \\ 2ririnoktaviani29@gmail.com
}

\section{Abstract}

The study aims to investigate the correlation between joining non-formal education and the English achievement of the second-grade students of SMA Negeri 2 Palembang. The problems of this study were: Is there any correlation between joining non-formal education and English achievement of the second-grade students of SMA Negeri 2 Palembang? And What does taking an English course gives impact toward English achievement of the second-grade students of SMA Negeri 2 Palembang? The method of this study used quantitative research. The total number of the sample was 52 students. The questionnaire and document were used to collect the data which were analyzed by using Pears on Product Moment correlation and Linear Regression analys is. The findings showed that: (1) there was a significant correlation between joining non-formal education and English achievement $(r=.845)$, (2) there was a significant impact of taking English courses and students' English achievement ( $p$-value $=.000)$.

\section{Key Words: Effect, Non-formal Education, and English Achievement.}

\section{INTRODUCTION}

English is one of the subjects that can make students become frightening and anxiety. It happens because of many factors, such as lack of vocabulary, self-confidence, low motivation, etc. From the statement above, there are so many ways to save the problem. One of the ways is through non-formal education. Non-formal education (NFE) is gathering practices that are not included in the formal system of education. According to Daryanto \& Farid (2013:26), non-formal education is an educational pathway informal education that can be implemented in a structured and tiered manner. Ahmati \& Uhbiyati (2015:164) state that non-formal education institution is all forms of education organized intentionally, orderly, and planned, outside of the school activities. Besides, Komar (2006:213), non-formal education is an education that is held outside the school through teaching and learning activities that do not have tiered, continuous, and whether institutionalized or not. Moreover, Novosadova, et al. (2006:9) state that non-formal education is an organized educational process which takes place alongside the mainstream systems of education and training and does not typically lead to certification. Non-formal education gives young people the possibility to develop their values, skills and competencies others than the ones developed in the framework of formal education.

From the above explanation, it is known that non-formal education is an education pathway that is held outside of the school activities for specific learning needs of individuals that relate with formal education and does not typically lead to certification. Non-formal education can handle educational activities that cannot be carried out through education therefore non-formal education as an addition or complement of formal education. Furthermore, non-formal education can help students to develop their values, skills, and competencies besides formal education.

The non-formal educations (NFE), which are not bounded by the government curriculum, are free to decide the conditions of the teaching process. It is different from formal education which is bounded by the government curriculum, organization system, and learning process. While there are many differences between formal and non-formal education but both of them complement each other. As mention in Pasal 13 Ayat 1 Undang-undang Nomor 20 Tahun 2003 about Sistem Pendidikan Nasional, "Education path consists of formal education, non-formal education and informal education that can complement and enrich each other." It means that non-formal education is one of the education pathways that can support formal education achievement.

Komar (2006:236) states that in legislation, non-formal education has units that include study 
groups, coursework, and similar educational units. Non-formal education organized in the form of playgroups, child care, and similar educational units. In Indonesia, non-formal education is common and easy to find in the form of courses or study groups. There are several types of non-formal education such as Science, Mathematics, Social Science, English Education, etc. From the explanation above, this study focuses on English Education based non-formal education in the form of courses. For the specific field, the researcher investigated the English course.

English course is one of non-formal education program which aims to improve the students' English ability. According to Astiyanti (as cited in Astuti, 2012:9), an English course in Indonesia is aimed only to improve the student English ability in daily life not for any other purpose. In brief, the English course is one of the education pathways that aims to improve the students' English ability and help them to understand the lesson based on their learning needs.

Therefore, the researcher wants to know scientifically the correlation between non-formal education and English achievement. From the stated explanation, the researcher was interested in conducting a researcher, entitled "The Correlation between Joining Non-Formal Education and English Achievement of the Second Grade Students of SMA Negeri 2 Palembang”.

\section{METHODOLOGY}

In this study, the researcher used quantitative research as an approach to answering the research question. Correlation design has been used in this study because the objective of the study is to find out whether or not there is a significant correlation between joining non-formal education and English achievement moreover to find out whether or not taking English course influence the students' English achievement. In this study, there was two variable, they were dependent variable and independent variable. The independent variable of this research is joining non-formal education $(X)$ which is measures through the dependent variable and the dependent variable is students' English achievement $(\mathrm{Y})$.

This research conducted in the Second Grade Students of SMA Negeri 2 Palembang in the academic year of 2017/2018. The researcher used purposive sampling or also called judgmental sampling to get a sample of the population. Based on the research needs the researchers chose class XI.MIPA.1, XI.MIPA.2, XI.MIPA.3, XI.MIPA.4, XI.MIPA.5, XI.MIPA.6 and took all of the students who take the English course. In this study, the researcher collected the data through questionnaires and the English report score. The researcher used a readymade questionnaire because the questionnaire was already used by the previous study written by Yunani in 2010. The kinds of the questionnaire are close-ended questions and the items of questionnaire consist of 20 questions. The questionnaires in this study are in the form of statements that have scales for each statement to measure the frequency of agreement. Moreover, the researcher took students' English scores in the last semester from the teacher's document. To classify the students' English achievement, the researcher used the score interval from SMA Negeri 2 Palembang that determined from the KKM English lesson.

The result of the questionnaire of each student calculated using percentage procedure to the students the variables based on the answers on the questionnaire. The researcher analyzed the data by using formula percentage, Sudijono (2017) states that in analyzing the data from the questionnaire used the calculation of the percentage procedure.

This study used correlation analysis to find out the correlation coefficient between the independent variable (Non-Formal Education) and the dependent variable (English achievement) of SMA Negeri 2 Palembang. The researcher used the operation of Pearson Product Moment Correlation using SPSS (Statistical Package for the Social Science) in SPSS 23.00 to analyze the data. Furthermore, simple Regression analysis is used to find out how much the influence variable $x$ and variable $Y$. 


\section{RESULT AND DISCUSSION}

In this study, students' English achievement was gathered from the English teacher of the second-grade students of SMA Negeri 2 Palembang. The frequency of students' English achievement was presented in the following table.

Table 1. The Total Results of Students' English Achievement

\begin{tabular}{lllllll}
\hline No. & Score Interval & Category & N & Percentage & Max Score & Min Score \\
\hline 1 & $93-100$ & Very Good & 7 & $14 \%$ & 96 & 93 \\
2 & $84-92$ & Good & 21 & $40 \%$ & 90 & 84 \\
3 & $75-83$ & Average & 24 & $46 \%$ & 83 & 75 \\
4 & $<75$ & Poor & 0 & 0 & 75 & - \\
\hline TOTAL & & 52 & $100 \%$ & \\
\hline
\end{tabular}

Based on the table above, it can be seen that there were no students got a poor score. There were 7 students (14\%) who got very good with the range score was 93-96, 21 students $(40 \%)$ got a good score with the range was $84-90$, and $24(46 \%)$ students got the average score with the range was 75-83. It was seen that the average of the students who joining non-formal education got a good score of their English achievement.

A questionnaire was distributed to the students who joining non-formal education particularly English courses to know the perception of the second-grade students of SMA Negeri 2 Palembang about non-formal education. The researcher distributed questionnaires to 52 samples, then reassembles their answers. The frequency of students' answers about the English course questionnaire was presented in the distribution score in the following table.

Table 2. The Results of Questionnaires

\begin{tabular}{ccccccc}
\hline No. & Score Interval & Category & N & Percentage & Max Score & Min Score \\
\hline 1 & $90-96$ & Very High & 6 & $12 \%$ & 96 & 92 \\
2 & $80-89$ & High & 13 & $25 \%$ & 88 & 80 \\
3 & $70-79$ & Average & 22 & $42 \%$ & 78 & 70 \\
4 & $65-69$ & Low & 7 & $13 \%$ & 69 & 65 \\
5 & $61-64$ & Very Low & 4 & $8 \%$ & 64 & 61 \\
\hline \multicolumn{7}{r}{} \\
\hline
\end{tabular}

Based on the table above, the result of the questionnaire showed that there were four students (8\%) who had very low with the range score was 61-64 and seven students (13\%) who got the low score with the range was 65-69, while there were twenty-two students (42\%) who had average with the range score was $70-78$, there were thirteen students $(25 \%)$ who had high with the range score was $80-88$ and there are only six students (12\%) who had very high with the range score was 92-96. It was seen that most of the students had an average score and there was a measly student who had a low score.

In this study used Pearson Product Moment Correlation analysis to see whether there was the correlation coefficient between the independent variable (Non-Formal Education) and the dependent variable (English achievement) of SMA Negeri 2 Palembang. The result of the correlation analysis can be seen in the following table. 
Table 3. The Result of Correlation Calculation

Correlations

\begin{tabular}{|cc|c|c|}
\hline & & NonFormal_Education & English_Achievement \\
\hline NonFormal_Education & Pearson Correlation & 1 & $.845^{* *}$ \\
& Sig. (2-tailed) & & .000 \\
& $\mathrm{~N}$ & 52 & 52 \\
\hline English_Achievement & Pearson Correlation & $.845^{* *}$ & 1 \\
& Sig. (2-tailed) & .000 & 52 \\
& $\mathrm{~N}$ & 52 & \\
\hline
\end{tabular}

${ }^{* \star}$. Correlation is significant at the 0.01 level (2-tailed).

The table showed that the correlation coefficient $\left(r_{x y}\right)$ was 0.845 . At the significance level $p<$ 0.05 in the tailed testing with $\mathrm{N}=52$, the critical value of the $r$-table is 0.845 . Since the value of $r$ obtained was higher than the critical value of $r$-table $(0.845>0.273)$. It means that there was a significant correlation between joining non-formal education and the English achievement of the second-grade students of SMA Negeri 2 Palembang.

Meanwhile, Simple Regression analysis was conducted to find out how much the influence variable $\mathrm{x}$ and variable $\mathrm{Y}$. The table below showed that the analysis of simple linear regression between joining non-formal education $(X)$ and students' English achievement $(Y)$.

Table 4. Model Summary Model Summary

\begin{tabular}{|c|c|c|c|c|}
\hline Model & $\mathrm{R}$ & R Square & Adjusted R Square & Std. Error of the Estimate \\
\hline 1 & $.845^{\mathrm{a}}$ & .713 & .708 & 4.801 \\
\hline
\end{tabular}

Based on the table above, the coefficient of determination $\left(\mathrm{r}^{2}\right)$, which represents variability in English achievement that is explained by the linear relationship between joining non-formal education and English achievement was 0.713 or 71.3 percent. It means that the influence of joining no-formal education was 0.713 or 71.3 percent.

$$
\begin{aligned}
I-r^{2} & =1-0.713 \\
& =0.287 \text { or } 28.7 \%
\end{aligned}
$$

It means that $28.7 \%$ of students' English achievement of the second-grade students of SMA Negeri 2 Palembang was determined by other factors. On the other hand, it can be said that there was an influence between joining non-formal education and English achievement.

Table 5. The Result of Regression

Coefficients
\begin{tabular}{|ll|l|l|l|l|l|}
\hline \multirow{2}{*}{\multicolumn{2}{|l|}{}} & \multicolumn{2}{|l|}{ Unstandardized Coefficients } & $\begin{array}{l}\text { Standardized } \\
\text { Coefficients }\end{array}$ & & \\
\cline { 3 - 5 } & & B & Std. Error & Beta & T & Sig. \\
\hline 1 & (Constant) & -52.637 & 11.623 & & -4.529 & .000 \\
& English_Achievement & 1.516 & .136 & .845 & 11.157 & .000 \\
\hline
\end{tabular}

From the table above, it can be seen that $t=11.157$ with significance was 0.000 , which means that the value was significant because of less than $0.05(0.000<0.05)$. On the other hand, $\mathrm{H}_{0}$ was 
rejected and $\mathrm{Ha}$ was accepted. So, there was an influence between joining non-formal education and students' English achievement.

Based on the findings, the English course is a part of non-formal education. English course purposes are to help and increase the students' English ability in their academics. In this study, by joining non-formal education, the students are hoped to have good ability in listening, speaking, writing, and reading skills. Non-formal education can affect SMA Negeri 2 Palembang students' in English. The reason because non-formal education is educative processes endowed for specific students' learning need and individuals are the actors actively involved in the education or learning process. In Indonesia, many English courses provide classes based on the students' skills need in English. Because of that reason, an English course that is a part of non-formal education might affect the students' English achievement.

Moreover, joining non-formal education is no guarantee that the students will get a good score in English achievement. The researcher found that some students got a lower score in their English achievement. Some students that might affect the students' English scores are learning interest and students' difficulties in learning English. The first factor is about learning interest. Some students did not have learning interest in learning English so they did not have the enthusiasm to learn English. This factor can affect students' achievement in learning English because interest is very important in learning and academic achievement. The second factor is about students' difficulties in learning English. Some students assumed that they had some difficulties in learning English so it could influence their English ability and achievement. There were several reasons why English was difficult for students. One of the reasons is a lack of vocabulary. The students usually feel apprehensive because they lack vocabulary when they speak, write, read or listen to English in their class. If the students learn more and practice, they can get a good score in their achievement.

This research tried to find correlation and influence of taking English courses and students' English achievement of SMA Negeri 2 Palembang. From the statistical analysis, the first finding showed that there was a significant correlation between joining non-formal education and English achievement of the second-grade students of SMA Negeri 2 Palembang. The correlation coefficient ( $\mathrm{r} x \mathrm{y})$ was 0.845 . At significance level $P<0.05(0.00<0.05)$ in the tailed testing with $\mathrm{N}=52$, the critical value of $r$-table is 0.271 . Since the value of $r$-obtained was higher than the critical value of $r$-table $(0.845>0.271)$. It had a positive correlation. It means that there was a very strong correlation between joining non-formal education and English achievement. $73 \%$ of students agreed that they understood while studying in an English course. In brief, the teacher who teaches in non-formal education is given the freedom to make learning methods appropriate to the goals so that the learning process is more interesting, enjoyable, active, and easy to understand. Because the students are actors actively involved in the learning process, the students will quickly understand the lesson is delivered by the teacher. With this condition, the students will have the chance to improve their English ability and increase their English score. Non-formal education was significantly correlated with students' English achievement, if the students enjoy non-formal education, the students will get a good score. In brief, based on the theories and facts, it could be claimed if there was a strong correlation between joining non-formal education (English course) and English achievement.

Furthermore, the second finding which was answered the research question number 2 . The result of the data showed that the significance $F$ value was 0.000 , which was smaller than $\propto=0.05$. It means that there was a significant influence of taking English courses towards students' English achievement. The contribution of taking an English course to the students' English achievement was 71.3\%. It proved that taking an English course influences the score obtained. On the other hand, $28.7 \%$ of students' English achievement of the second-grade students of SMA Negeri 2 Palembang was determined by other factors. The other aspect that might contribute to students' English achievement is motivation. $65 \%$ of students agreed that they want to take more time to learn English. It can be seen that they had a high motivation to learn English. It concluded that motivation is a crucial 
factor in learning English which is influenced by the students' English achievement. Moreover, $65 \%$ of students agreed that they join an English course from their parents. Motivation is not only come from their students but also come from their parents. When the students felt forced to join an English course, it will influence their achievement. That is why there were some students got low scores although they joined the English course. Therefore, the role of parents, teachers, and their students is very important in building the students' motivation to learn English, thus it could influence the students' achievement

\section{CONCLUSION}

Regarding the findings, the researcher concluded that there was a correlation between joining non-formal education and students' English achievement. Non-formal education can help the students to increase their English achievement because non-formal education is flexible and practical which possibly makes the students more understand in English. The teacher who teaches in non-formal education is given the freedom to make learning methods appropriate to the goals so that the learning process is more interesting, enjoyable, active, and easy to understand. Because the students are actors actively involved in the learning process, the students will quickly understand the lesson which is delivered by the teacher. With this condition, the students will have the chance to improve their English ability and increase their English score. Besides, the researcher concluded that there was an influence of taking an English course on students' English achievement. English course contributed to students' English achievement. The contribution given from the English course to English achievement was $71.3 \%$. The other aspect that might contribute to students' English achievement is motivation. Motivation is a crucial factor in learning English which is influenced by the students' English achievement. 65\% of students agreed that they join an English course with their parents. Motivation is not only come from their students but also come from their parents. When the students felt forced to join an English course, it will influence their achievement. That is why there were some students got low scores although they joined the English course. Therefore, the role of parents, teachers, and their students is very important in building the students' motivation to learn English, thus it could influence the students' achievement.

Based on the conclusion, there are two points that the researcher wants to suggest. Those suggestions are dedicated to English teachers, students, and other researchers. The English teachers should know the characteristic of the students, so they can improve the techniques of teaching English that can cover all of the students. By knowing the character of the students, the teacher is expected to give a contribution and pay more attention to students who have a lower score in learning English, thus they can increase their English achievement. The teacher should give motivation and opportunity for the students to improve their English and makes learning activities more interesting. Besides, the teacher could encourage the students to read more, watch English movies, listen to English songs, improve their vocabulary, and practice more.

Meanwhile, the students should know their ability in learning English. If students have some difficulties in English, they should try to find out the way to increase their ability. Students are encouraged to join the English course, practice every day, keep a notebook of new words students learn, use English whenever students can, memorization of vocabulary, reading for fun, etc. Students should increase their motivation in learning English because motivation is an important factor in the English teaching and learning process. Besides that, the other researcher can get an additional source for their similar topic and added their knowledge about joining non-formal education especially the English course. 


\section{REFERENCIES}

Astuti, S. (2012). The Comparison of Students' Who Take English Course Out Side of School and Their English Achievement in Reading Comprehension of the Students Who Do Not Take English Course in the Eighth Grade Students of the Junior High School Sriguna of Palembang. Palembang: PGRI University of Palembang.

Daryanto, \& Farid, M. (2013). Konsep Dasar Manajemen Pendidikan di Sekolah. Yogyakarta: Gava Media.

Komar, O. (2006). Filsafat Pendidikan Nonformal. Bandung: Pustaka Setia.

Loveta, G. (2016). The Correlation between Joining Non-Formal Education and speaking's SkillS in SMP Negeri 18 Palembang. Palembang: Sriwijaya University.

Melnic, A. S., \& Botes, N. (2014). Formal, Non-formal and Informal Interdependence in Education. Economy Transdisciplinarity Cognition, 17 (1), 113-118.

Novosadova, M., Selen, G., Asia, Arnold, A., Agata, Patrik, et al. (2006). NFE Book: The Impact of NFE on Young People Society. Belgium: AEGE-EUROPE.

Salkind, N. J. (2013). Statistic for People Who (Think They) Hate Statistics. London: SAGE Publication.

Sudijono, A. (2017). Pengantar Statistik Pendidikan. Jakarta: Rajagarfindo Persada.

Sugiyono. (2017). Metode Penelitian kuantitatif, kualitatif, dan R\&D. Bandung: Alfabeta.

Yunani. (2010). The Influence of Joining English Course Towards English Achievement of theSecond Grade Students of State Islamic Junior High School (MTS N) of Salatiga in the Academic year of 2009/2010. Salatiga: State Islamic Studies Institute (STAIN). 